\title{
Study on the Cultivation of Agaricus blazei (Almond Mushroom) Grown on Compost Mixed with Selected Agro-Residues
}

\author{
Tun Tun Win, Shoji Ohga \\ Faculty of Agriculture, Kyushu University, Fukuoka, Japan \\ Email:ohga@forest.kyushu-u.ac.jp, tuntunwin.namma@gmail.com
}

How to cite this paper: Win, T.T. and Ohga, S. (2018) Study on the Cultivation of Agaricus blazei (Almond Mushroom) Grown on Compost Mixed with Selected Agro-Residues. Advances in Microbiology, 8, 778-789.

https://doi.org/10.4236/aim.2018.810051

Received: August 17, 2018

Accepted: October 8, 2018

Published: October 11, 2018

Copyright $\odot 2018$ by authors and Scientific Research Publishing Inc. This work is licensed under the Creative Commons Attribution International License (CC BY 4.0).

http://creativecommons.org/licenses/by/4.0/

\begin{abstract}
The Agaricus blazei strain (KUMB 1221) from Forest Production Control Laboratory, Kyushu University was grown on the basal media of compost mixed with selected agro-residues (sawdust, woodchips and corncob) in the ratio of $25 \%, 50 \%, 75 \%$ and $100 \%$ (by weight). The data was collected on the colony diameter of mycelial growth, days required for spawn run (colonization), days required for primordial formation, whiteness measurement, days required for fruit body formation, number, size and fresh weight of mushrooms, biological efficiency (BE) and mushroom production (MP). It was observed that the mycelial growth showed two types of mycelia according the level of mycelial density; compact (C) and somewhat compact (SC). The fastest spawn run (17 days) was found in woodchips (50\%) among all the different treatments while the least spawn run took 26 days in corncob (75\%). Sawdust substrates promoted longer days for primordial formation and fruit body development, if compared with woodchips substrates and corncob substrates. With regard to yield, $100 \%, 75 \%$ and $50 \%$ mixture with compost were superior to $25 \%$ mixture with compost in each group of selected agro-residues and it indicated that adding more compost gave the increased yield. Interestingly, it was noted that mushroom size on compost (100\%) was double to the mushroom size of other treatments. In conclusion, it was clearly showed that compost (100\%), woodchips (25\%) and corncob (25\%) could produce better yields among all treatments, and it was also possible to obtain acceptable yields of good quality almond mushroom using main substrates of compost mixed with different agro-residues at various concentrations.
\end{abstract}

\section{Keywords}

Agaricus blazei, Mushroom Cultivation, Agro-Residues, Compost, Substrate 


\section{Introduction}

Mushrooms are an important product in global trade with an estimated production of 3.4 million metric tons in 2007 [1]. They have attracted the attention of the biotechnological industries as food supplements or materials for developing medicines [2]. The mushroom species of Agaricus blazei (Cogumelo do sol), Agaricus bisporus (Champignon), Pleurotus sajor-caju (Oyster mushroom) and Lentinula edodes (Shiitake) are of important economic value on account of their exquisite flavor and proven medicinal properties [3]. The A. blazei is naturally found on organic litter which has already been occupied by the first stage decomposers capable of digesting complex lignocellulosic components [4]. It has been referred to by various names, in China as Gee Song Rong or Brazilian mushroom, in Brazil as mushroom of God (Cogumelo de Deus) or mushroom of the Sun (Cogumelo do Sol) [4] and Himematsutake in Japan [5]. Recently, it was discovered that both mycelium and fruiting bodies of almond mushroom unusually have high concentrations of beta glucans, immune-potentiating polysaccharides, which also inhibit the growth of malignant tumors [5]. Then, the popularity of this mushroom is increasing rapidly.

Nowadays it is also cultivated at the industrial level in Japan, China and Korea [6]. With regard to its production level, it is still very low compared to A. bisporus [7], thus, it is needed to develop substrate meeting requirements of almond mushroom and to produce higher biological efficiency. A cheap and stable source for commercial purpose is still sought. Stamets reported that each mushroom species thrives on a limited range of substrates and strains within a species are even more specific in their habitat requirements, temperature preferences, and their flushing intervals [8]. Hence, it is still necessary to develop a proper technology and adapt its each species requirements for cultivation due to different ecological conditions of the countries. Even though horse manure with combination is used as basal media for cultivation, several researchers have modified the composition of the substrates by using different agro-residues compost to increase its yield. There is no standard formulation for substrate compositions and on the other hand, few scientific studies have still compared the effectiveness of different substrates on the productivity of the almond mushroom. Therefore, this study was conducted to investigate better commercial cultivation of $A$. bla$z e i$ through revealing better biological efficiency and productivity by using main compost mixed with selected agro-residues.

\section{Materials and Methods}

\subsection{Mushroom Strain/Fungal Culture}

The A. blazei strain (KUMB 1221) was obtained from Forest Production Control Laboratory, Kyushu University. It was cultured on potato dextrose agar (PDA) previously autoclaved at $121^{\circ} \mathrm{C}$ for $15 \mathrm{~min}$, kept at $25^{\circ} \mathrm{C} \pm 1^{\circ} \mathrm{C}$ in the dark and sub-cultured every three months. The inoculum was selected from the mycelium growth border with uniform appearance and with sectioning. 


\subsection{Compost}

One-year fermented horse manure bedding compost was used as a basal ingredient for producing spawn as well as substrate preparation. The compost was directly obtained from a local livestock company (Japan Agriculture (JA), Itoshima).

\subsection{Substrate Preparation, Inoculation, Incubation and Casing}

The compost was mixed with selected agro-residues; sawdust (hardwood), woodchips (hardwood) and corncob, in the ratio of $25 \%, 50 \%, 75 \%$ and $100 \%$ (by weight) (e.g. compost/sawdust 1:3, 1:1, 3:1, and 1:0). Rice bran and wheat bran were used as supplementary substances to increase mushroom yield and to achieve faster mycelial growth. Each mixture of the substrates was supplemented by $20 \%(\mathrm{w} / \mathrm{w})$ while $100 \%$ compost substrate was supplemented by $50 \%$ and mixed thoroughly. To adjust moisture content (MC), pre-tests were conducted and it was found that $60 \%$ of $\mathrm{MC}$ was the best condition for mycelial growth. Thus, the prepared substrates were adjusted to $60 \%$ moisture with tap water and the $\mathrm{pH}$ of substrates was measured.

The wet substrates of $700 \mathrm{~g}$ were added into polypropylene bags having holes on one side of the upper part (breathing patches) and $100 \mathrm{~g}$ were set in the petri dish for mycelial growth measurement, then sterilized both at $121^{\circ} \mathrm{C}$ for $1 \mathrm{hr}$. After that, they were moved to the wind-stream of a laminar flow hood and allowed to cool to the desired inoculation temperature. $700 \mathrm{~g}$ of wet substrates were inoculated by inoculum (2\%) containing mother spawn and agar cultures while $5 \mathrm{~mm}$ disc of agar culture was inoculated for mycelium colony diameter in the petri dishes. Inoculum was placed in the middle of each petri dish and special care was taken to keep the cylinder mycelium in direct contact with each substrate.

The bags were marked by permanent marker and were kept on the shelves in the incubation room, where the temperature was maintained at $23^{\circ} \mathrm{C}$, relative humidity at $80 \%, \mathrm{CO}_{2}$ level at $1000 \mathrm{ppm}$ by automatic aeration, and were allowed to compete the whitish mycelial growth. In case of the inoculated petri dishes, they were incubated at $25^{\circ} \mathrm{C}$ in the darkness. During this period, bags were shaken daily, so that fungal mycelia may uniformly be mixed and cover around the materials. After the substrates were completely colonized with the fungal mycelia, the bags were torn apart and cased with $3.5-4 \mathrm{~cm}$ of local soil over the surface of the substrate by hand and kept in a fruiting environment where the temperature was maintained at $18.5^{\circ} \mathrm{C}-21.5^{\circ} \mathrm{C}$, relative humidity at $85 \%$ and having good ventilation. Casing soil was sieved $(2 \mathrm{~mm})$ to remove roots and stones, then it was used without heat treatment or chemical treatments. Daily moderate watering was done in order to keep the casing layer humid, not over-soaked until the end of cultivation. In order to stimulate cased substrate, the procedure of ruffling was conducted. Ruffling implies that the mycelium is mixed by lightly raking the casing soil layer, to get a more uniform mycelium 
growth, the ruffling procedure will break the mycelium in the casing soil layer, stimulating regrowth.

\subsection{Evaluated Parameters}

The data was collected on colony diameter of mycelial growth, days required for spawn run (colonization), days required for primordial formation, whiteness measurement, days required for fruit body formation, number, size and fresh weight of mushrooms, biological efficiency (BE) and mushroom production (MP).

\subsubsection{Diameter Measurement of Mycelial Growth}

The mycelial growth was measured after 7 days of growth for two weeks and recorded photographically at the end of experiment. Levels of mycelial density among the treatments were compared visually and categorized by $\mathrm{T}$ (thin), ST (somewhat thin), Co (compact) and SC (somewhat compact).

\subsubsection{Spawn Run and Primordial Formation}

The duration required for completion of hypha spreading varies in accordance with the volume of the medium is called spawn run and primordial formation is started from the day of casing to the day when the first pins are verified.

\subsubsection{Whiteness Percentage}

Color analysis is one of the most important factors to determine the mycelial quality of mushroom. Before casing, MINOLTA CR-200 was used to analyze the whiteness percentage of different substrates covered with completely colonized mycelia. Then, the data was calculated by the following formula:

$$
\mathrm{Z}=(1-\mathrm{x}-\mathrm{y}) / \mathrm{y}^{\star} \mathrm{Y} \text {, then } \mathrm{Z} / 1.18 \text {. }
$$

\subsubsection{Mushroom Number, Size and Fresh Weight}

The number, size and fresh weight were regularly determined during the harvesting phase. Average mushroom size was calculated as fresh weight of mushrooms (FWM) (g) divided by number of mushrooms per bag and expressed as $\mathrm{g} /$ mushroom. Mushrooms were harvested in the morning and later in the afternoon, when they reached the maximum size; the sides of the pileus were parallel and before the veil opened. After the uncut mushrooms were harvested, the base of each stipe was cleaned with a brush, so that they could be weighed without any soil pieces.

\subsubsection{Biological Efficiency and Mushroom Production}

Mushroom yields expressed as percentage of BE and MP. BE (\%) was determined by the equation of

$$
\mathrm{BE}=\mathrm{FWM} / \text { Dry weight of substrate (DWS) }{ }^{\star} 100 \text {, }
$$

while MP (\%) was determined by the equation of

$$
\mathrm{MP}=\mathrm{FWM} / \text { Fresh weight of substrate (FWS)*100. }
$$

\subsubsection{Experimental Design and Statistical Analysis}

A completely randomized design was adopted with three replicates per treat- 
ment and SATISTIX 8.1 was used to determine the differences among the averages by the analysis of variance, then the means were compared by Tukey's test $(\mathrm{p}<0.05)$.

\section{Results}

\subsection{Effect of Different Substrate Formulations on Vegetative Growth, Mycelial Density and Whiteness Percentage}

The results obtained for the colony diameter measurement, mycelial density and whiteness percentage on different substrate formulations of compost mixed with selected agro-residues are given in Table 1 . It was observed that the mycelial growth showed two types of mycelia according the level of mycelial density (Figure 1). While substrates with $75 \%$ and $50 \%$ of sawdust, $75 \%$ of corncob, and $100 \%$ of compost supported Co level of mycelial density, other remaining treatments supported a more vigorous mycelial density as SC. Healthy and outstanding mycelium is a vital part which reflects the overall growth and productivity.

At the end of experiments, the substrate containing sawdust (50\%) (72.34 $\mathrm{mm}$ ) was the best for mycelial extension followed by sawdust (75\%) $(62.41 \mathrm{~mm})$, woodchips $(25 \%)(62.11 \mathrm{~mm})$, woodchips $(75 \%)(61.17 \mathrm{~mm})$ and woodchips (50\%) $(58.11 \mathrm{~mm})$, sawdust $(25 \%)(48.64 \mathrm{~mm})$, compost $(100 \%)(39.93 \mathrm{~mm})$, corncob (50\%) (34.28 mm), corncob (75\%) (22.73 mm) and corncob (25\%) (8.63 $\mathrm{mm})$ respectively. There were not significant differences between woodchips and sawdust treatments, but they were significant difference from corncob treatments. Poor mycelial extension was observed in all the corncob treatments and they stood up below compost (100\%).

All studied bags showed healthy white vigorous and rhizomorphic mycelia. With regard to different substrates' whiteness measurement, sawdust (50\%), compost (100\%) and sawdust (75\%) supported the better whiteness percentage of 51.06, 50.26 and 50.13, but, there were no apparent differences among all treatments.

\subsection{Effect on Spawn Run, Primordial Formation and Fruit Body Development}

The duration required for spawn run, primordial formation and fruit body development depends on the substrates used and the results are presented in Table 2. The fastest spawn run (17 days) was found in woodchips (50\%) among all the different treatments while the least spawn run took 26 days in corncob (75\%). Except in sawdust (25\%), sawdust (75\%) and corncob (75\%), all remaining treatments ran spawn faster than compost (100\%) (22 days). Like mycelial colony diameter comparison, it was observed that substrates containing 50:50 mixture with compost (17 days in woodchips, 18 days in both sawdust and corncob) gave more rapid spawn run than other mixtures. It can be said that mycelial colony diameter was negatively correlated to spawn run in each treatment.

Counting the total days required for primordial formation and fruit body development were started after transferring fully colonized bags into the growing 
Table 1. Mycelial growth, mycelial density and whiteness percentage of different substrate formulations.

\begin{tabular}{|c|c|c|c|c|}
\hline \multirow{2}{*}{ Types of Substrates } & \multicolumn{2}{|c|}{ Colony Diameter (mm) } & \multirow{2}{*}{ Mycelial Density } & \multirow{2}{*}{ Whiteness (\%) } \\
\hline & First Week & Second Week & & \\
\hline Woodchips (75\%) & $23.28 \pm 2.23 b$ & $61.17 \pm 9.20 \mathrm{ab}$ & SC & $42.06 \pm 4.17 \mathrm{a}$ \\
\hline Woodchips (50\%) & $24.07 \pm 1.61 b$ & $58.11 \pm 12.95 \mathrm{ab}$ & SC & $47.95 \pm 3.81 \mathrm{a}$ \\
\hline Woodchips (25\%) & $23.16 \pm 2.82 b$ & $62.11 \pm 10.12 \mathrm{ab}$ & SC & $44.64 \pm 5.22 \mathrm{a}$ \\
\hline Sawdust (75\%) & $24.91 \pm 3.22 b$ & $62.41 \pm 7.04 \mathrm{ab}$ & Co & $50.13 \pm 4.88 \mathrm{a}$ \\
\hline Sawdust (50\%) & $30.61 \pm 2.31 \mathrm{a}$ & $72.34 \pm 13.94 a$ & Co & $51.06 \pm 4.86 \mathrm{a}$ \\
\hline Sawdust (25\%) & $25.64 \pm 3.29 b$ & $48.64 \pm 11.81 b c$ & SC & $47.09 \pm 6.55 \mathrm{a}$ \\
\hline Corncob (75\%) & $5.73 \pm 0.91 \mathrm{~d}$ & $22.73 \pm 5.85 \mathrm{de}$ & Co & $43.70 \pm 9.30 \mathrm{a}$ \\
\hline Corncob (50\%) & $12.79 \pm 5.09 \mathrm{c}$ & $34.28 \pm 18.62 \mathrm{~cd}$ & SC & $47.72 \pm 8.95 \mathrm{a}$ \\
\hline Corncob (25\%) & $5.10 \pm 0.05 \mathrm{~d}$ & $8.63 \pm 0.29 \mathrm{e}$ & SC & $43.60 \pm 5.79 \mathrm{a}$ \\
\hline Compost (100\%) & $22.59 \pm 2.11 b$ & $39.93 \pm 8.99 c$ & Co & $50.26 \pm 2.24 \mathrm{a}$ \\
\hline
\end{tabular}

Values are the mean \pm standard deviation. Means followed by the same letter in the same column are not significantly different according to Tukey's HSD.

Table 2. Total day to spawn run, primordial formation, fruit body development of different substrates.

\begin{tabular}{ccccc}
\hline Types of Substrates & Spawn Run & Primordial Formation & $\begin{array}{c}\text { Fruit Body } \\
\text { Development }\end{array}$ & $\begin{array}{c}\text { Total Day to } \\
\text { First Crop }\end{array}$ \\
\hline Woodchips (75\%) & 21 & 12 & 18 & 39 \\
Woodchips (50\%) & 17 & 14 & 20 & 37 \\
Woodchips (25\%) & 20 & 10 & 15 & 35 \\
Sawdust (75\%) & 25 & 19 & 26 & 51 \\
Sawdust (50\%) & 18 & 28 & 35 & 53 \\
Sawdust (25\%) & 23 & 28 & 34 & 57 \\
Corncob (75\%) & 26 & 11 & 18 & 44 \\
Corncob (50\%) & 18 & 16 & 22 & 40 \\
Corncob (25\%) & 20 & 16 & 22 & 42 \\
Compost (100\%) & 22 & 13 & 18 & 40 \\
\hline
\end{tabular}

Values are the mean. Means followed by the same letter in the same column are not significantly different according to Tukey's HSD.

incubator and casing with local soil (Figure 2). The primordial formation in terms of pin heads was observed in all treatments and the duration required for primordial formation was found to be variable for treatments. Sawdust substrates promoted longer days for primordial formation and fruit body development, if compared with woodchips substrates and corncob substrates. The shortest primordial formation was observed in woodchips (25\%) at 10 days, then followed by 11 days, 12 days, 13 days, 14 days, 16 days, 19 days and 28 days with corncob (75\%), woodchips (75\%), compost (100\%), woodchips (50\%), corncob 


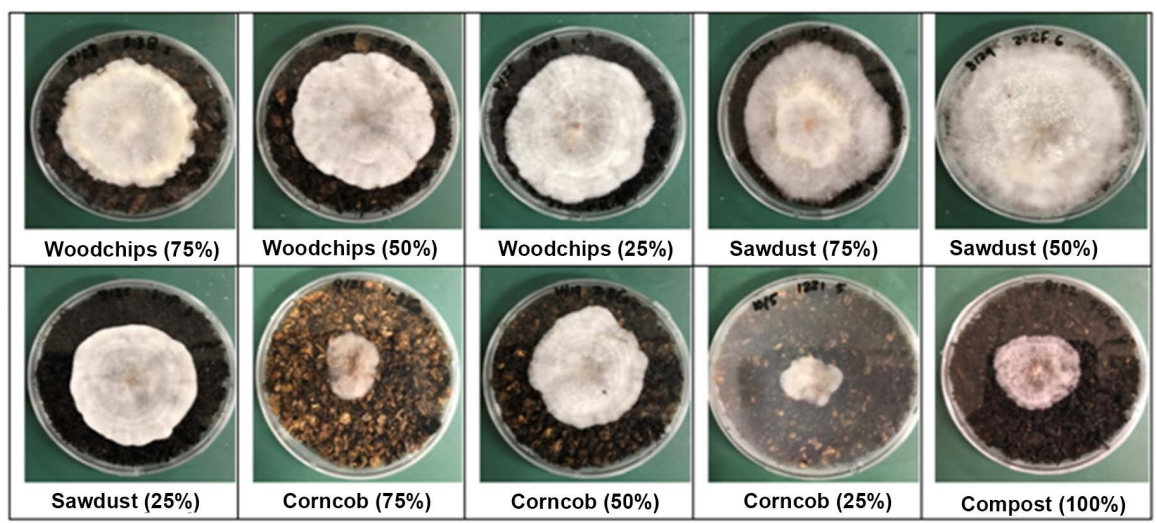

Figure 1. Comparison of mycelial growth of $A$. blazei on various concentrations of agro-residues with compost after two-week.
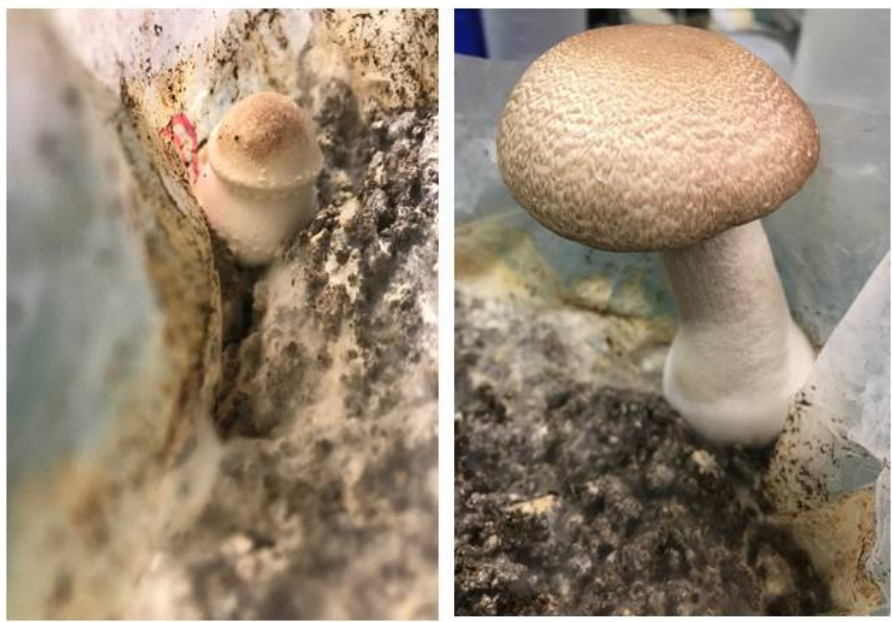

Figure 2. Primordial formation and fruit body development of almond mushroom.

(50\%), corncob (25\%), sawdust (75\%), sawdust (50\%) and sawdust (25\%) respectively. These results suggested that spawn run did not necessarily reflect faster primordial formation and fruiting body development. It took 5 - 7 days from primordial formation to fruit body development and was in the range of 35 - 57 days for total day to the first crop.

\subsection{Effect on Biological Efficiency, Mushroom Production, Weight and Size}

$\mathrm{BE}, \mathrm{MP}$ and size of mushroom varied widely, depending on the mushroom, substrate, and conditions. Table 3 shows the results obtained for BE, MP, weight and size using different substrates in accordance with the experimental design for almond mushroom cultivation. During the reproductive stage of mushroom, two flushes were found and almost $90 \%$ yield has been harvested during the first flush. But, not all bags produced in the second flush. Therefore, the yield data for only first flush was used to compare the effectiveness of different substrates in this study. 
Table 3. Total fresh weight, biological efficiency, mushroom production and size on different substrates.

\begin{tabular}{ccccc}
\hline Types of Substrates & Total Fresh Weight (g) & BE (\%) & MP (\%) & Size (g) \\
\hline Woodchips (75\%) & $69.00 \pm 2.40 \mathrm{~g}$ & $22.63 \mathrm{~g}$ & $9.86 \mathrm{~g}$ & $34.50 \pm 1.20 \mathrm{e}$ \\
Woodchips (50\%) & $69.60 \pm 3.81 \mathrm{~g}$ & $22.83 \mathrm{~g}$ & $9.94 \mathrm{~g}$ & $34.80 \pm 0.75 \mathrm{e}$ \\
Woodchips (25\%) & $162.11 \pm 4.34 \mathrm{~b}$ & $53.17 \mathrm{~b}$ & $23.16 \mathrm{~b}$ & $40.53 \pm 1.09 \mathrm{~b}$ \\
Sawdust (75\%) & $76.00 \pm 2.40 \mathrm{f}$ & $24.92 \mathrm{f}$ & $10.86 \mathrm{f}$ & $38.00 \pm 1.20 \mathrm{~d}$ \\
Sawdust (50\%) & $76.20 \pm 2.60 \mathrm{f}$ & $24.99 \mathrm{f}$ & $10.89 \mathrm{f}$ & $38.10 \pm 1.30 \mathrm{~cd}$ \\
Sawdust (25\%) & $115.20 \pm 1.50 \mathrm{e}$ & $37.78 \mathrm{e}$ & $16.46 \mathrm{e}$ & $38.40 \pm 0.50 \mathrm{c}$ \\
Corncob (75\%) & $61.00 \pm 2.60 \mathrm{~h}$ & $20.01 \mathrm{~h}$ & $8.71 \mathrm{~h}$ & $30.50 \pm 1.30 \mathrm{~g}$ \\
Corncob (50\%) & $126.40 \pm 4.36 \mathrm{~d}$ & $41.45 \mathrm{~d}$ & $18.06 \mathrm{~d}$ & $31.60 \pm 1.09 \mathrm{f}$ \\
Corncob (25\%) & $138.40 \pm 6.56 \mathrm{c}$ & $45.39 \mathrm{c}$ & $19.77 \mathrm{c}$ & $34.60 \pm 1.64 \mathrm{e}$ \\
Compost (100\%) & $189.50 \pm 3.97 \mathrm{a}$ & $62.15 \mathrm{a}$ & $27.07 \mathrm{a}$ & $94.75 \pm 1.98 \mathrm{a}$ \\
\hline
\end{tabular}

Values are the mean \pm standard deviation. Means followed by the same letter in the same column are not significantly different according to Tukey's HSD.

Among the conditions evaluated, the suitable substrates promoting the maximum yield in terms of weight, BE and MP were composted of compost (100\%) (189.50 g, BE of $62.15 \%$, MP of $27.07 \%)$, woodchips (25\%) (162.11 g, BE of $53.17 \%$, MP of $23.16 \%$ ), corncob (25\%) (138.40 g, BE of $45.39 \%$, MP of $19.77 \%$ ), corncob (50\%) (126.40 g, BE of $41.45 \%$, MP of 18.06\%) and sawdust (25\%) (115.20 g, BE of $37.78 \%$, MP of $16.46 \%$ ), and they were statistically significant difference from others. Then it was followed by sawdust (50\%), sawdust (75\%), woodchips (50\%), woodchips (75\%) and corncob (75\%) with a corresponding yield of $76.20 \mathrm{~g}, 76.00 \mathrm{~g}, 69.60 \mathrm{~g}, 69.00 \mathrm{~g}$, and $61.00 \mathrm{~g}$ respectively. In each group of selected agro-residues, $100 \%, 75 \%$ and $50 \%$ mixture with compost were superior to $25 \%$ mixture with compost and it indicated that adding more compost gave the increased yield.

Size of fruit bodies was significantly large on compost (100\%) (94.75 g) followed by woodchips (25\%), sawdust (25\%), sawdust (50\%), sawdust (75\%), woodchips (50\%), corncob (25\%), woodchips (75\%), corncob (50\%) and corncob (75\%) with $40.53 \mathrm{~g}, 38.40 \mathrm{~g}, 38.10 \mathrm{~g}, 38.00 \mathrm{~g}, 34.80 \mathrm{~g}, 34.60 \mathrm{~g}, 34.50 \mathrm{~g}, 31.60 \mathrm{~g}$ and 30.50 $\mathrm{g}$ respectively. Among groups, corncob gave the smallest size of mushroom and interestingly, it was noted that mushroom size on compost (100\%) was double to the mushroom size of other treatments.

\section{Discussion}

Materials for composing a mushroom substrate are diverse and plentiful. The selection of the substrate components is more critical for growing gourmet mushrooms indoors than for growing outdoors [9]. The substrates containing higher composts promoted better mycelial extension, but in our result, substrates containing 50\% mixture with compost gave better mycelial extension when compared 
with other mixture of $25 \%, 75 \%$ and $100 \%$ except in woodchips treatments [10] [11]. High mineral nutrients, high moisture accumulation, accumulation of toxic products, changes in factors such as $\mathrm{pH}$ and rise in temperature inside the substrate could be the factors which affect mycelial growth. The particle size and pore of substrates were also responsible for the more mycelium growth rate. While the smaller particles stimulate quick growth, the larger particles encourage the mycelium to form thick and cord like strands. Substrates with larger particles present higher $\mathrm{O}_{2}$ and lower $\mathrm{CO}_{2}$ levels, and higher $\mathrm{O}_{2}$ and $\mathrm{CO}_{2}$ levels stimulate and inhibit growth, respectively [12].

Suitable substrates lead to faster colonization and a higher density of mycelium, enhance primordial formation and fructification, and increase mushroom yield [13]. The spawn run usually takes 15 - 20 days depending on climate conditions and those results are partially similar to our findings [14]. The fastest spawn run was 38 days in substrate containing 75:25 mixture (sawdust with compost) while took 31 days as the fastest spawn run in new sugarcane compost [14] [15]. The harvesting time of $A$. blazei is relatively long (approximately 60 days) when compared to other related Agaricus species, including A. bisporus (approximately 30 days). The Brazilian cultivar ABL-99/30 had a time to fruiting of 24.7 - 27 days after casing on sugarcane-based composts [16]. Moreover, 18 24 days for primordial formation after applying casing soil, and 4 - 8 days for fruit body development after primordial formation, which total day to the first flush was 50 - 72 days [17]. Our result was supportive of those above mentioned findings, but it was longer growing cycle from casing to the first harvest than presented the growing cycle was around 20 - 21 days. The 90\% of mushrooms were harvested 91 days after casing. The delay fruiting is an economic problem for mushroom cultivation.

Substrates were enriched with higher content of nutrients by adding supplements, thus, it provided the maximum yield at the first flush [18] [19]. The compactness or poor aeration of the substrates after the first flush caused the reduction in yield. Both higher amounts of supplements and compost could provide better yield because it contained higher nutrient contents and water holding capacity (WHC) [20] [21]. It had been reported that the BE of almond mushroom in rice or wheat straw compost was about 30 - 40 [22]. The differences in physical and chemical composition of substrate formulas, C:N ratio inside substrates, mineral contents, moisture content, $\mathrm{pH}$ and electrical conductivity (EC) of substrate caused the differences in terms of BE and MP on grown on different substrates. Not only sole compost with supplements but also suitable combinations of compost with agro-residues could provide acceptable yield in this study. The greatest number of fruit body and large size were seen where yield was the highest [23] [24]. It showed that number and size of fruit bodies and yield were positively correlated to each other. Different mushroom strain, less nutrients in compost, lower moisture in casing or compost and other environmental factors could be the reason for mushroom's size differentiation. 


\section{Conclusion}

The $A$. blazei is an important edible mushroom and an interesting alternative one to developing countries due to its multiple advantages such as food, medicine and cosmetic uses. It was clearly showed that compost (100\%), woodchips (25\%) and corncob (25\%) could produce higher BE and MP than others. It was also possible to obtain acceptable yields of good quality almond mushroom using substrates in different concentrations with different agro-residues, woodchips, sawdust and corncob. Furthermore, the substrates used in this study can be considered practically and economically feasible because utilization of these agro-residues is constantly available throughout the year in large quantities with low cost. However, it is impossible to produce $A$. blazei on non-composted substrates. Despite the observed differences among substrates, the mushroom yield obtained is still low to be economically practical in this study. The yield of the production should be improved to reach a commercial scale. Attempts to improve the yield depend on several factors such as casing soil, casing technology, optimal substrate formulations, particle size, spawn type, supplement type and the inoculum rate, the environmental factors and selection of the strains.

\section{Conflicts of Interest}

The authors declare no conflicts of interest regarding the publication of this paper.

\section{References}

[1] Linde, G.A., Alessandra, T., Nunes, R., Domingues, G., Figueiredo, E.F., Santin, K.C. and Colauto, N.B. (2014) Mushroom Acceptability and Consumption Intention for the Main Mushrooms Produced in Brazil. Postgraduate Program in Biotechnology Applied to Agriculture, Paranaense University, Umuarama, 627-632.

[2] Mizuno, T. (2002) Medicinal Properties and Clinical Effects of Culinary-Medicinal Mushroom Agaricus blazei Murrill (Agaricomycetideae) (Review). International Journal of Medicinal Mushrooms, 4, 35-44. https://doi.org/10.1615/IntJMedMushr.v4.i4.30

[3] Silva, C.F., Azevedo, R.S., Braga, C., Silva, R. and Dias, E.S. (2009) Microbial Diversity in a Bagasse-Based Compost Prepared for the Production of Agaricus brasiliensis. Brazilian Journal of Microbiology, 40, 590-600. https://doi.org/10.1590/S1517-83822009000300023

[4] Gregori, A., Pahor, B., Glaser, R. and Pohleven, F. (2008) Influence of Carbon Dioxide, Inoculum Rate, Amount and Mixing of Casing Soil on Agaricus blazei Fruiting Bodies Yield. Acta Agriculturae Slovenica, 91, 371-378. https://doi.org/10.2478/v10014-008-0017-2

[5] Stijve, B.T., Angela, M., Amazonas, L.D.A. and Florestas, E. (2004) The Royal Sun Agaricus or Himematsutake-An Update. Mushroom Science, 22, 47-50.

[6] Llarena-Hernández, C.R., Largeteau, M.L., Ferrer, N., Regnault-Roger, C. and Savoie, J.M. (2014) Optimization of the Cultivation Conditions for Mushroom Production with European Wild Strains of Agaricus subrufescens and Brazilian Cultivars. Journal of the Science of Food and Agriculture, 94, 77-84.

https://doi.org/10.1002/jsfa.6200 
[7] De Siqueira, F.G., Dias, E.S., Silva, R., Tokuda, E. and Rinker, D.L. (2009) Cultivation of Agaricus blazei ss. Heinemann Using Different Soils as Source of Casing Materials. Victoria, 66, 827-830.

[8] Stamets, P. (1993) Growing Gourmet and Medicinal Mushrooms. Ten Speed Press, Berkeley.

[9] Wang, Q., Li, B.B., Li, H. and Han, J.R. (2010) Yield, Dry Matter and Polysaccharides Content of the Mushroom Agaricus blazei Produced on Asparagus Straw Substrate. Scientia Horticulturae, 125, 16-18. https://doi.org/10.1016/j.scienta.2010.02.022

[10] Horm, V. and Ohga, S. (2008) Potential of Compost with Some Added Supplementary Materials on the Development of Agaricus blazei Murill. Journal of the Faculty of Agriculture, Kyushu University, 53, 417-422.

[11] Pokhrel, C.P. and Ohga, S. (2007) Cattle Bedding Waste Used as a Substrate in the Cultivation of Agaricus blazei Murill. Journal of the Faculty of Agriculture, Kyushu University, 52, 295-298.

[12] Chu, J.N., Young, C.C., Tan, C.C., Wu, S.P. and Young, L. (2012) Improvement of Productivity and Polysaccharide-Protein Complex in Agaricus blazei. Pesquisa Agropecuária Brasileira, 47, 96-102. https://doi.org/10.1590/S0100-204X2012000100013

[13] De Mendonca, M., Kasuya, M.C., Cadorin, A. and Vieira, A.J. (2005) Shiitake Cultivation Part II Mushroom for Better Life.

[14] Lentinula, S. and Spawn, E. (2003) Supplementation of Sugarcane Bagasse with Rice Bran and Sugarcane Molasses for Shiitake. Brazilian Journal of Microbiology, 34 , 61-65. https://doi.org/10.1590/S1517-83822003000100013

[15] Pardo-Giménez, A., Zied, D.C. and Pardo-González, J.E. (2010) Utilización de compost agotado de champiñón como capa de coberturas en nuevos ciclos de producción. Pesquisa Agropecuaria Brasileira, 45, 1164-1171. https://doi.org/10.1590/S0100-204X2010001000016

[16] Stamets, P. (2000) Growing Gourmet and Medicinal Mushrooms. 3rd Edition, Ten Speed Press, Berkeley, 208-216.

[17] Colauto, N.B., Da Eira, A.F. and Linde, G.A. (2012) Cryopreservation of Agarius blazei in Liquid Nitrogen Using DMSO as Cryoprotectant. Bioscience Journal, 28, 1034-1037.

[18] Colauto, N.B., da Silveria, A.R., da Eira, A.F. and Linde, G.A. (2011) Production Flush of Agaricus blazei on Brazilian Casing Layers. Brazilian Journal of Microbiol$o g y, 42,616-623$.

[19] Da Eira, A.F. (2003) Cultivo do cogumelo medicinal Agaricus blazei (Murril) ss. Heinemann ou Agaricus brasiliensis (Wasser et al.) CPT. https://books.google.co.jp/books?id=WZFIAAAACAAJ

[20] De Andrade, M.C.N., Kopytowski Filho, J., Minhoni, M.T.D.A., Coutinho, L.N. and Figueiredo, M.B. (2007) Productivity, Biological Efficiency, and Number of Agaricus blazei Mushrooms Grown in Compost in the Presence of Trichoderma sp. and Chaetomium olivacearum Contaminants. Brazilian Journal of Microbiology, 38, 243-247. https://doi.org/10.1590/S1517-83822007000200010

[21] Kerrigan, R.W. (2005) Agaricus subrufescens, a Cultivated Edible and Medicinal Mushroom, and Its Synonyms. Mycologia, 97, 12-24. https://doi.org/10.1080/15572536.2006.11832834

[22] Kim, H.H., Na, J.G., Chang, Y.K., Chun, G.T., Lee, S.J. and Jeong, Y.H. (2004) Op- 
timization of Submerged Culture Conditions for Mycelial Growth and Exopolysaccharides Production by Agaricus blazei. Journal of Microbiology and Biotechnology, 14, 944-951.

[23] Wang, H., Fu, Z. and Han, C. (2013) The Medicinal Values of Culinary-Medicinal Royal Sun Mushroom (Agaricus blazei Murrill), 2013.

[24] Zied, D.C., Pardo-Giménez, A., de Almeida Minhoni, M.T., Villas Boas, R.L., Alvarez-Orti, M. and Pardo-González, J.E. (2012) Characterization, Feasibility and Optimization of Agaricus subrufescens Growth Based on Chemical Elements on Casing Layer. Saudi Journal of Biological Sciences, 19, 343-347.

https://doi.org/10.1016/j.sjbs.2012.04.002 